\title{
Erratum: Noradrenergic control of error perseveration in medial prefrontal cortex
}

\section{Mark Laubach*}

The John B. Pierce Laboratory, New Haven, CT, USA

${ }^{*}$ Correspondence: mark.laubach@yale.edu

Edited by:

Jeremy Seamans, University of British Columbia, Canada

\section{A commentary on}

Noradrenergic

control of error perseveration in medial prefrontal cortex by Caetano, M. S., Jin, L. E., Harenberg, L., Stachenfeld, K. L., Arnsten, A. F. T., and Laubach, M. (2013). Front. Integr. Neurosci. 6:125. doi: 10.3389/fnint.2012.00125

The paper should have listed support from the National Science Foundation (NSF). Two authors (Stachenfeld and
Laubach) were supported with funds from NSF grant 1121147 to Mark Laubach.

The correct acknowledgment is:

"This work was supported by Public Health Service Grant PO1AG030004 from the National Institute on Aging (Amy F. T. Arnsten and Mark Laubach), the National Science Foundation 1121147 (Mark Laubach) and by AFAR/Ellison Medical Foundation Post-doctoral Fellowship (Marcelo S. Caetano).”
Received: 28 May 2013; accepted: 06 June 2013; published online: 26 June 2013.

Citation: Laubach M (2013) Erratum: Noradrenergic control of error perseveration in medial prefrontal cortex. Front. Integr. Neurosci. 7:48. doi: 10.3389/fnint. 2013.00048

Copyright (c) 2013 Laubach. This is an openaccess article distributed under the terms of the Creative Commons Attribution License, which permits use, distribution and reproduction in other forums, provided the original authors and source are credited and subject to any copyright notices concerning any third-party graphics etc. 